\title{
TAPHONOMIC ASPECTS OF DEER (MAMMAliA, CETARTIODACTYLA, CERVIDAE) REMAINS FROM A QUATERNARY CAVE DEPOSIT IN NORTHERN BRAZIL
}

\section{Victoria Maldonado ${ }^{1}$, Lucas Guimarães Pereira Monteiro ${ }^{2}$, Alline RotTi ${ }^{3}$, Carolina Pereira $^{4}$, Hermínio Ismael DE ARAújo-Júnior ${ }^{5}$ AND LEONARDo dos SANTOS AVILla ${ }^{4, *}$}

1 Undergraduate student of Environmental Sciences, Universidade Federal do Estado do Rio de Janeiro, Av. Pasteur, 458, Urca, 22240-290, Rio de Janeiro, Rio de Janeiro State, Brazil. vi_maldonado@hotmail.com

2 Undergraduate student of Geology, Faculdade de Geologia, Universidade do Estado do Rio de Janeiro, Rua São Francisco Xavier, 524, Maracanã, 20550-013, Rio de Janeiro, Rio de Janeiro State, Brazil. lucasgpmonteiro@gmail.com

3 Undergraduate student of Biological Sciences, Universidade Federal do Estado do Rio de Janeiro, Av. Pasteur, 458, Urca, 22240-290, Rio de Janeiro, Rio de Janeiro State, Brazil. allinerotti@gmail.com

4 Laboratório de Mastozoologia, Departamento de Zoologia, Universidade Federal do Estado do Rio de Janeiro, Av. Pasteur, 458, Urca, 22240-290, Rio de Janeiro, Rio de Janeiro State, Brazil. caca-p@bol.com.br; leonardo.avilla@gmail.com

5 Departamento de Estratigrafia e Paleontologia, Faculdade de Geologia, Universidade do Estado do Rio de Janeiro, Rua São Francisco Xavier, 524, Maracanã, 20550-013, Rio de Janeiro, Rio de Janeiro State, Brazil. herminio.ismael@yahoo.com.br

*CORRESPONDING AUTHOR, leonardo.avilla@gmail.com

Received on 20 April 2016

Received in revised form on 18 May 2016

Accepted on 24 May 2016

\section{Editor:}

Maria Virginia Alves Martins, Universidade do Estado do Rio de Janeiro, Brazil

\section{Abstract}

This work identifies and interprets taphonomic features of the deer fossil assemblage recovered from the Gruta do Urso cave, located in Tocantins State, Northern Brazil. Consequently, its results shed light on the origin of the vertebrate assemblages in cave deposits and paleoecological aspects of Quaternary deer of northern Brazil. The cervid fossil accumulation of the Gruta do Urso cave includes individuals of three species that died outside the cave and, then, underwent disarticulation and weathering during a time span between one and five years. During the necrolysis, they experienced scavenging by large-sized felids and small-sized

\section{Introduction}

Brazilian caves outstand by preserving a large amount of vertebrate remains of Quaternary age, including
Citation:

Maldonado, V., Monteiro, L.G.P., Rotti, A., Pereira, C., Araújo-Júnior, H.I., Leonardo dos Santos Avilla, L.S., 2016. Taphonomic aspects of deer (Mammalia, Cetartiodactyla, Cervidae) remains from a Quaternary cave deposit in Northern Brazil. Journal of Sedimentary Environments, 1(2): 228-241.

canids. Then, the disarticulated remains and a mummified hindlimb were transported into the cave by multiple events of low-energy hydraulic flows. Inside the cave, some specimens experienced exposure on the water table and incrustation. The biostratinomic data suggest the taphonomic history of deers around Gruta do Urso cave occurred in arid conditions.

Keywords: Taphonomy. Paleoecology. Cave deposits. Cervidae. Quaternary.

megamammals and large-, mid- and small-sized vertebrates that lived in South America from the Late Pleistocene to the 
Holocene (Cabral-de-Carvalho et al., 1969; Cartelle, 1992; Auler et al., 2006). However, few taphonomic studies were conducted in Brazilian caves so far (e.g. Auler et al., 2006; Hubbe et al., 2011; Hubbe and Auler, 2012). The comprehension of the taphonomic history of a fossil assemblage deposited in caves is important to determine how those fossils were transported to the cave, if those fossils used the cave as shelter, and even to study some paleoecological aspects, such as food web role and environmental preferences (Andrews, 1990; Simms, 1994).

This work aims to identify and interpret the taphonomic features of the deer fossil assemblage recovered from the Gruta do Urso cave, located in Tocantins State, Northern Brazil. Consequently, this work shed light on the taphonomic history and paleoecological aspects of Late Quaternary vertebrates preserved in Brazilian caves.

\section{Study area}

\subsection{Location and genesis of the caves}

The material was recovered from a sedimentary deposit at the Gruta do Urso limestone cave in Aurora do Tocantins $\left(12^{\circ} 42^{\prime} 47^{\prime \prime} \mathrm{S}\right.$ and $\left.46^{\circ} 24^{\prime} 28^{\prime \prime} \mathrm{W}\right)$, Tocantins State, northern Brazil (Fig. 1). The carbonate rocks from Aurora do Tocantins are part of the Speleological Province of the Bambuí Group, where numerous caves have been found (Zampaulo and Ferreira, 2009). The geology of the study area is poorly known. The predominant rocks in the region are rhythmic limestones and siltstones from the Neoproterozoic Paraopeba Subgroup, although alluvial deposits might occur locally (Dardenne, 1978; Dardenne and Walde, 1979).

The information provided by the Serviço Geológico do Brasil on the geology of the municipality of Aurora do Tocantins report carbonate and terrigenous deposits (CPRM, 2006). The lower portion of the area is represented by the Sete Lagoas Formation, which is composed of thick deposits of mudstones, calcareous and dolomites presenting stromatolites.

The Sete Lagoas Formation is covered by siltstone and laminate siltstones of the Serra de Santa Helena Formation. This carbonate-terrigenous set of rocks is superimposed by dark calcarenites and marls, with organic material from the Lagoa do Jacaré Formation. Superimposed over the Bambuí Group are the Cretaceous rocks of the Urucuia Formation.

The caves were developed mainly in the limestones of Lagoa do Jacaré Formation, which consist in slightly weathered dark gray metacalcarenites, massive or with horizontal lamination, with sparry calcite (generally in veins), micritic calcite, ooids and small amounts of silica. In some outcrops there are interbedded metacalcarenites, mudstones and calcilutites (Avilla et al., 2013). Millimeter- to centimeterwide whitish gray intraclasts occur throughout the predominant limestones (CPRM, 2006).

The limestones often form plateaus that rise from the rest of the terrain and comprise a partially active karst system. Most caves occur above the ground level in high portions of the plateaus. The caves originated during a period of formation of karst relief in which the rocks that now compose the plateaus were below the ground level. The current outcrops were not developed by the uplift of the plateaus, but by the different types of erosion of the limestones and the erosive retraction of the Urucuia sandstones which once covered the region and today occur to the east of the study area (Avilla et al., 2013). Access to the plateaus occurs mainly through vicinal roads and paths that cut the vegetation. Currently, the region is situated mainly within the Cerrado biome.

The Gruta do Urso cave is an epigenic, solutional, ramiform to network cave with some branchwork passages (sensu Palmer, 1991) and has great vertical and horizontal development. The entire length of the cave has not been completely mapped. The Gruta do Urso cave originated in a phreatic zone, was later invaded and enlarged by vadose water.

\subsection{Stratigraphy}

The fossils described here were collected from 2011 to 2014 in the Gruta do Urso limestone cave at Aurora do Tocantins (12 $42^{\prime} 47^{\prime \prime}$ S; 46 $\left.24^{\prime} 28^{\prime \prime} \mathrm{W}\right)$, state of Tocantins, northern Brazil. All excavations were leaded by the Professor Leonardo dos Santos Avilla, director of the Laboratório de Mastozoologia of Universidade Federal do Estado do Rio de Janeiro - UNIRIO.

The fossils were found in a sedimentary deposit of a lateral passage of the main room. The excavation within the cave was stratigraphically controlled, and three stratigraphic levels were recognized (from the bottom to the top): 1) a 16 millimeter-thick yellowish layer of coarser granulometry, containing several detached angular clasts originated from the cave walls; 2) a laminated reddish-grey loess-like sediment with granulometry from very fine to fin, with a thickness of 180 to 220 millimeters; only this layer (level 2) contained fossil remains; and, 3) a superficial thin layer, composed of sands cemented by $\mathrm{CaCO}_{3}$; this layer is around $2 \mathrm{~cm}$ thick (Fig. 2). 

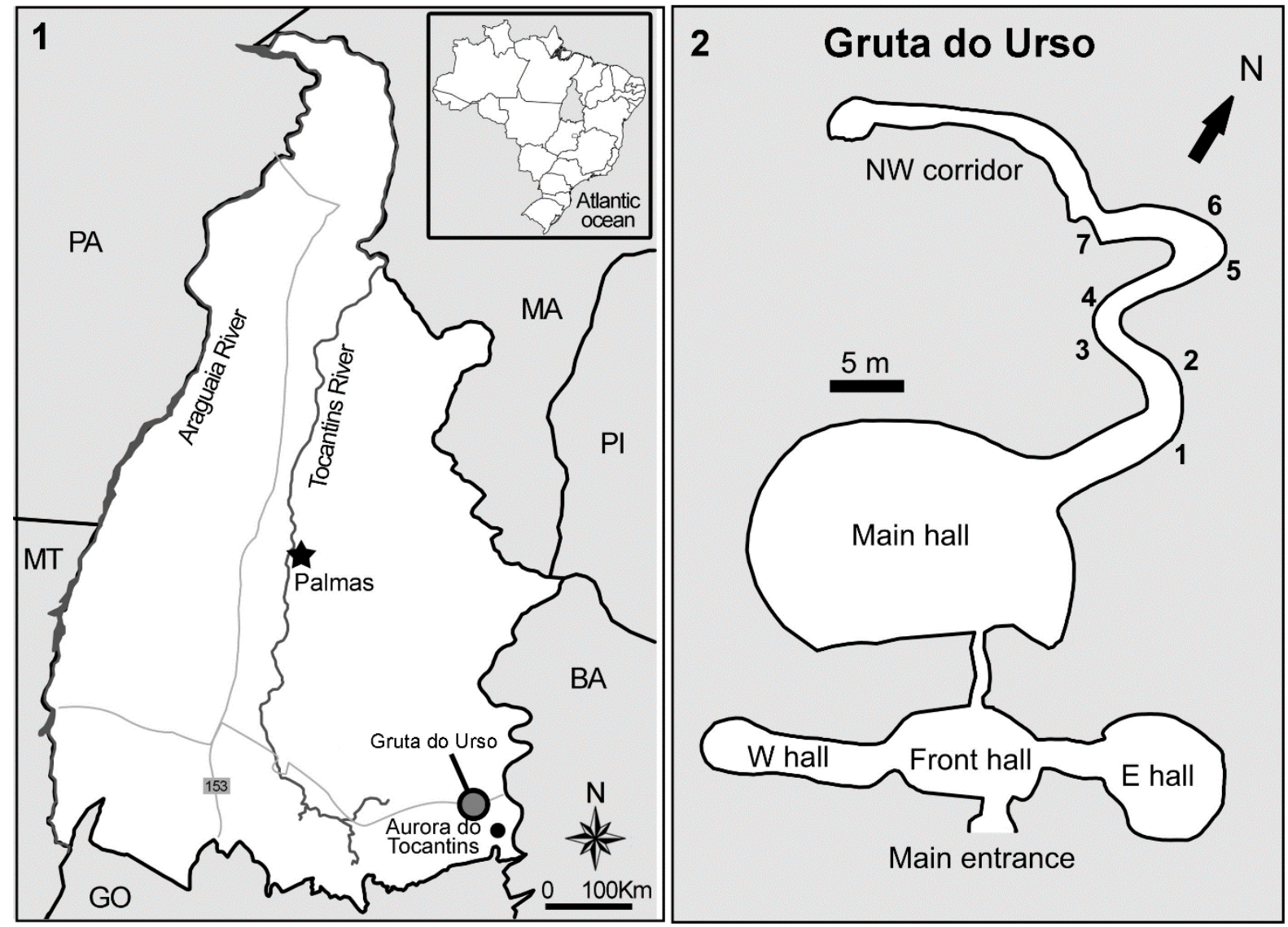

Fig. 1. Location map of Gruta do Urso cave and Aurora do Tocantins, Tocantins State, Northern Brazil. 1. Location map of the study area; 2. Map of the interior of the cave; numbers inside the cave represent the sequence of curves of the conduit.

The occurrence of sedimentary deposits covered by carbonate incrustation lenses is also observed in many other caves in the region of Aurora do Tocantins, possibly corresponding to a large scale event of increased humidity, causing changes in the pattern of recharge from the land surface and consequently in the entire environment. Similar occurrences were studied by Auler et al. (2009), who identified three processes (clastic sediment input, erosion and calcite deposition) that are linked to distinct paleoenvironmental and paleoclimatic conditions.

The episodes of clastic input would be related to a drier climate, sparse vegetation and intense sediment yield due to runoff, while the precipitation of calcite would be related to wetter conditions (Auler and Farrant, 1999; Brain, 1995; Brook et al., 1997). Sediment erosion inside those caves can be interpreted as cause of intermediate climatic conditions, which were not humid enough for speleothem deposition and not dry enough to allow transportation of sediment into the caves (Auler et al., 2009).

Although there is no absolute dating for the Cervidae remains, their age can be discussed based on both numerical datings for other taxa and the faunal assemblage found associated at that same level. Fossils of Panthera onca (Linnaeus, 1758) found at the bottom and Morenelaphus Carette, 1922 from the top of the fossiliferous level gave dates ranging from about 22,000 and 3,800 BP, respectively (Rodrigues et al., 2014). Furthermore, the armadillo Propraopus sulcatus (Lund, 1842) is restricted to the Late Pleistocene (see Castro et al., 2013) and the equid Equus (Amerbippus) neogeus (Lund, 1840) is a fossil guide for Lujanian (Late Pleistocene-earliest Holocene; Cione and Tonni, 1999, 2005). Therefore, the Cervidae fossils herein studied can be attributed to the Late Pleistocene-early Holocene age. 


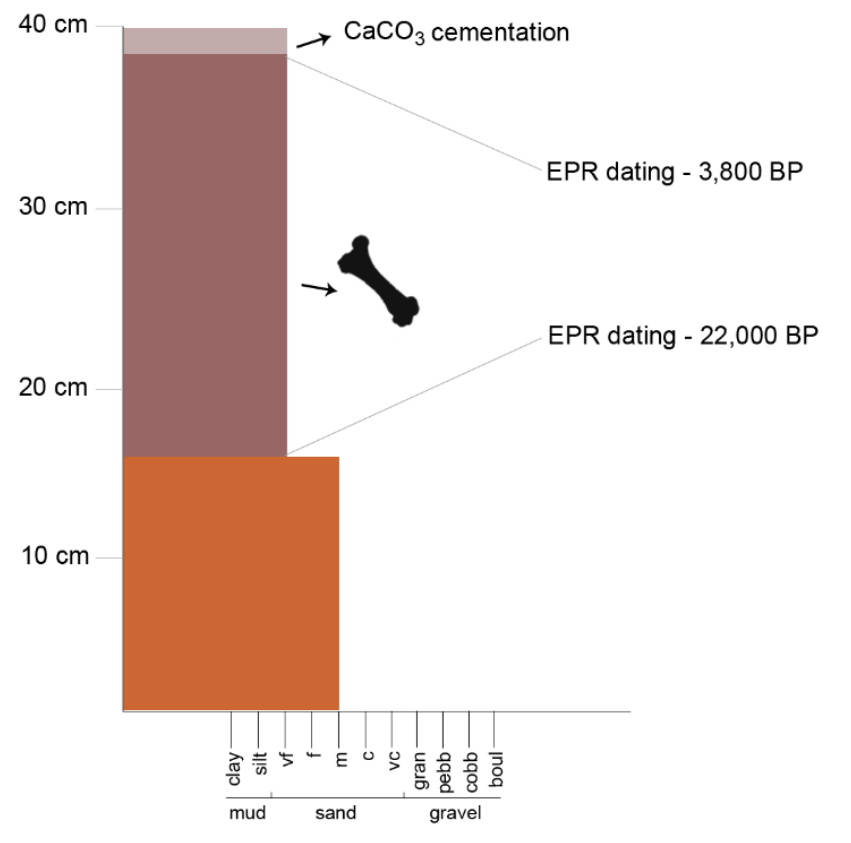

Vertebrate remains

Fig. 2. Stratigraphic log of the fossiliferous deposit of Gruta do Urso.

\section{Material and methods}

\subsection{Excavation, preparation and description}

The material was collected in four excavations (January/2011, January/2012, June/2013 and January/2014) in the Gruta do Urso. During the paleontological expeditions to the caves of northern Brazil, great diversity and abundance of fossil of mammals were gathered and they are housed at the collection of fossil mammals at the UNIRIO (Oliveira et al., 2011; Avilla et al., 2013; Rodriguez et al., 2013; Castro et al., 2013; Rodrigues et al., 2014; Villa Nova et al., 2015; Soibelzon et al., 2015; Gasparini et al., 2015). Deer remains were recovered in the four expeditions, providing us specimens enough to base this study.

The fossils were collected by digging and picking them from the sedimentary deposit. After the curatorial procedures (cleaning and formal inclusion in the collection) in the laboratory, each fossil was identified by its taxonomy and anatomy. The taxonomical identification were based on visiting extant (Mastozoology Section of Museu Nacional) and fossil mammalian collections (Museu de Ciências Naturais da Pontifícia Universidade Católica; MCL). The anatomical identification was also based on Sisson and Grossman (2008), Schmid (1972), Scherer (2009), and also using a complete skeleton of Mazama americana (UNIRIOPM 4970). The measurements used a digital calliper and were based on Scherer (2009).

\subsection{Taphonomic analysis}

The material is composed of 28 specimens belonging to the Cervidae (Mammalia, Cetartiodactyla) and is housed in the paleomastozoological collection of the Laboratório de Mastozoologia (LAMAS) da Universidade Federal do Estado do Rio de Janeiro (UNIRIO). All specimens and sedimentological data were recovered during four fieldworks at Gruta do Urso. Bone modification criteria provided by Haynes (1980, 1983), Hill (1980), Shipman (1981), Behrensmeyer (1978, 1991), Lyman (1994) and Eberth et al. (2007a, b). Taphonomic attributes evaluated were: (i) taxonomic representation; (ii) bone representation; (iii) weathering; (iv) breakage; (v) abrasion; (vi) incrustation; (vii) scavenging; (viii) color pattern; and (ix) aspects of transport.

The taxonomic representation was evaluated taking into account the Number of Identifiable Skeletal Parts (NISP) and the Minimum Number of Individuals (MNI) to quantify taxa and skeletal parts, respectively (Lyman, 1994; Badgley, 1986). For each taxon, the MNI was calculated using the most abundant skeletal element from either the left or right side of the animal (Lyman, 1994). Taxonomic representation consists in identifying the taxa recorded in the fossil accumulation and the amount of skeletal elements per taxa. Bone representation is related to the amount of specific skeletal parts preserved in the fossil assemblage (Lyman, 1994).

Weathering and abrasion were evaluated using the Behrensmeyer's weathering stages (from zero to five; Behrensmeyer, 1978) and Shipman's abrasion stages (no abrasion; moderate abrasion; heavy abrasion; Shipman, 1981), respectively. Regarding the breakage, we consider only long bones (e.g. tibiae, humeri, femurs) and used the classification of Shipman et al. (1981) for types of fractures. We establish three stages of incrustation: (i) stage 0 , bony surface not covered by concretions; (ii) stage 1, until $50 \%$ of the bony surface covered by concretions; and (iii) stage 2 , up to $50 \%$ of the bony surface covered by concretions. The description and interpretation of tooth traces are based on 
Haynes (1980, 1983), Mikuláš et al. (2006) and Pirrone et al. (2014). Color assignments were based on the Munsell Color Chart. Regarding the aspects of transport, we apply the Voorhies' groups (Voorhies, 1969) in order to infer the distance of transport of the remains from their source area. Then, using aspects of transport and abrasion, we classify the Cervidae assemblage according to the classification of fossil vertebrate assemblages of Araújo-Júnior (2016; in situpreserved assemblage; peripheral assemblage; ex situpreserved assemblage).

\section{Results}

\subsection{Abundance and size classes}

Twenty-eight post-cranial elements assigned to cervids were identified. They were assigned previously to Blastoceros dichotomus, Mazama gouazoubira and Mazama americana by Pereira (2015). Three bodied size classes were recognized among the cervid specimens of Gruta do Urso cave: Largesized cervids (LC), mid-sized cervids (MC) and small-sized cervids (SC). All skeletal elements belong to adult individuals, as their epiphyses are fused to the diaphyses. The abundance of individuals per size classes was defined using the MNI, allowing recognizing five cervid individuals: one LC individual, two MC individuals and two SC individuals.

\subsection{Surface bone modifications}

The taphonomic analysis performed herein is based on the data presented in the Appendix 1 and Appendix 2.

Regarding the weathering stages, the stage 1 is overrepresented in the sample (78.6\% of the sample) (Fig. $3 \mathrm{D}, \mathrm{E})$. The commonest features are shallow cracks parallel to the major axes. Around $10.7 \%$ of the sample is assigned to the stage 0 (Fig. 3C). Only a specimen (UNIRIO-PM $4815)$ presents stage 2 of weathering (3.6\% of the sample) (Fig. 5A). Due to the presence of incrustation, weathering stages were not attributed to $7.1 \%$ of the sample (see Fig. 3B).

Bone removal of the distal epiphyses of four elements (UNIRIO-PM 3461, UNIRIO-PM 3454, UNIRIO-PM 3471 and UNIRIO-PM 3472) were observed. The specimen UNIRIO-PM 3459 (Fig. 3A) also presents an irregularshaped bone removal which is deeper than those observed in other specimens. Furthermore, there is a wide exposition of the cancellous bone of the epiphysis of this specimen. Shallow scratches were observed in the calcaneus UNIRIO-
PM 4813 (Fig. 4D). They form a set of scratches parallel each other and perpendicular to the major axis of the calcaneus.

Fractures are observed in $71.4 \%$ of the specimens. Among the broken specimens, 95\% present irregular fractures perpendicular to the major axis. Around the specimen UNIRIO-PM 3476 (Fig. 3E) presents spiral fracture $(5 \%$ of the broken specimens). Interestingly, all broken elements are fractured near the central part of the diaphysis.

Wear marks are rare in the cervid specimens and an only specimen presents signs of this sort (UNIRIO-PM 3455). Regarding the Voorhies' groups, only the groups I (32.2\%) and II $(67.8 \%)$ are represented. Although collected isolated, some skeletal elements were associated a posteriori, during the taphonomic analysis (Appendix 1). However, the most significant association is made between the skeletal elements of a hindlimb: the right tibia (UNIRIO-PM 4814), the right metatarsus (UNIRIO-PM 4815), tarsal bones, calcaneus and astragalus (UNIRIO-PM 4816). All these elements were visually cemented by $\mathrm{CaCO}_{3}$ (Fig. 4A, B).

Incrustation was observed on around $93 \%$ of the sample. Among the encrusted bones, $84.6 \%$ are in the Stage 1 and $15.4 \%$ in the Stage 2. Only two specimens (UNIRIO-PM 3461 and UNIRIO-PM 3468) do not present signs of incrustation (that is, they are assigned to the Stage 0 ). Surface color of the specimens is assigned to the yellowish pattern yellow HUE 5Y (8/4 and 8/6) of the Munsell Color Chart. Furthermore, some specimens present staining by darkish minerals (Appendix 2). Regarding the color pattern of the incrustations, some bones vary from yellow-red HUE 2.5YR to yellow-red HUE 10YR, depending on the amount of siliciclastic sediments associated to the incrustation (Appendix 2).

\section{Discussion}

This taphonomic analysis indicates that the deer specimens of Gruta do Urso cave experienced an array of taphonomic processes during their taphonomic history. Interestingly, the large amount of inferred taphonomic processes is related to the biostratinomic phase (Behrensmeyer, 1991).

The presence of the earlier stages of desiccation marks in the cervid specimens suggests that these elements experienced weathering prior to burial during a time span between one to five years (Behrensmeyer, 1978). That categorization of weathering was based on systematic observations and describes five stages with liked time of exposure in an arid climate. 
A
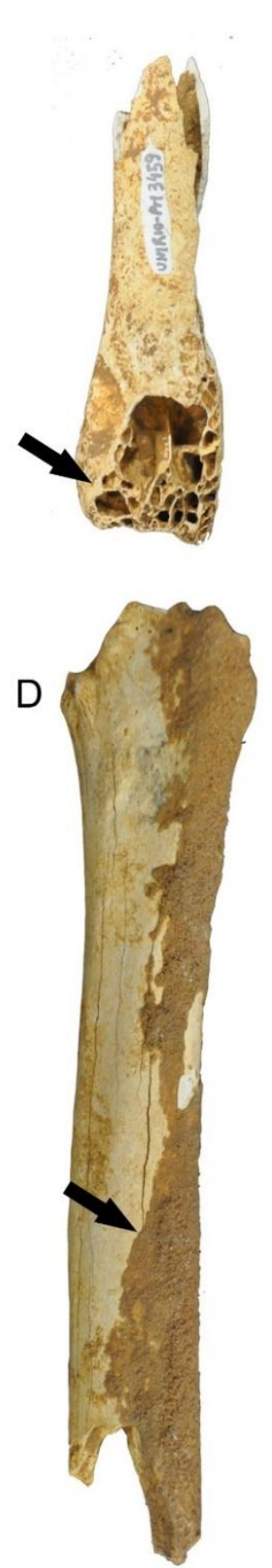

B

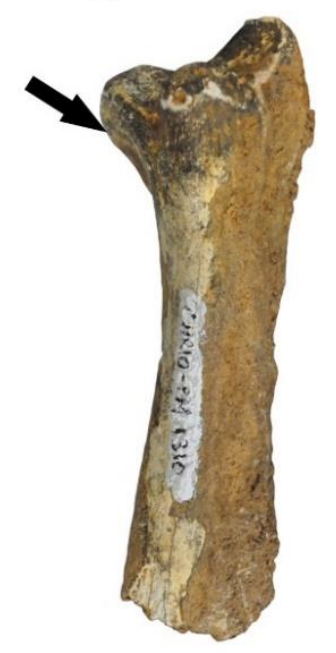

C

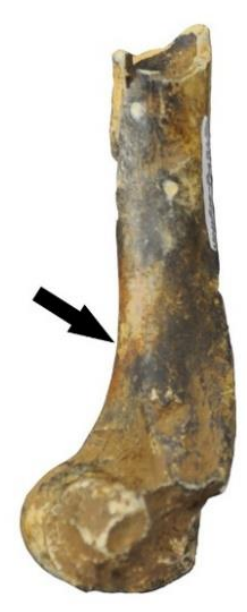

E

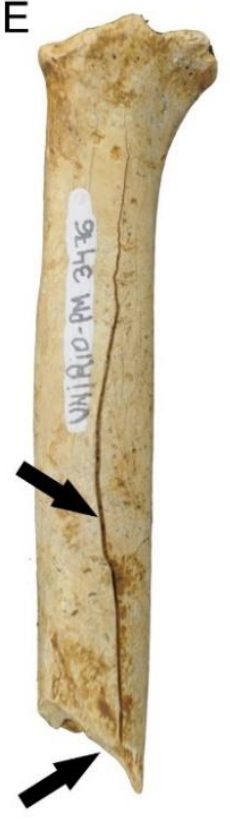

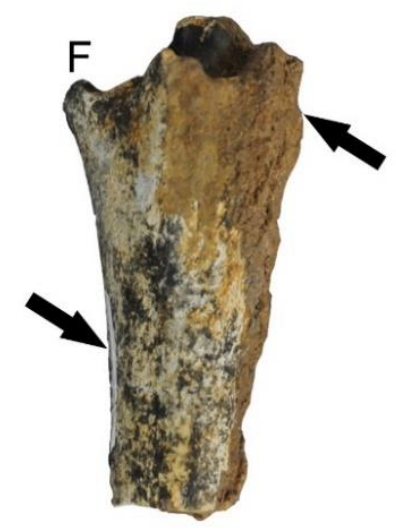

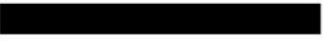

Fig. 3. Taphonomic features observed in the deer remains from Gruta do Urso cave. A. UNIRIO-PM 3459, distal fragment of left femur with drying bone removal caused by dryness of the epiphyseal cartilages; B. UNIRIO-PM 1310, proximal fragment of left tibia with black staining; C. UNIRIO-PM 3454, distal fragment of right humerus with two types of staining; D. UNIRIO-PM 4814, proximal fragment of right tibia with stage 1 of incrustation; E. UNIRIO-PM 3476, proximal fragment of right radius with weathering stage 1 and spiral fracture; F. UNIRIO-PM 3460, proximal fragment of right tibia with blackish staining and stage 1 of incrustation; arrows indicate taphonomic signatures. Scale bar $=5 \mathrm{~cm}$. 

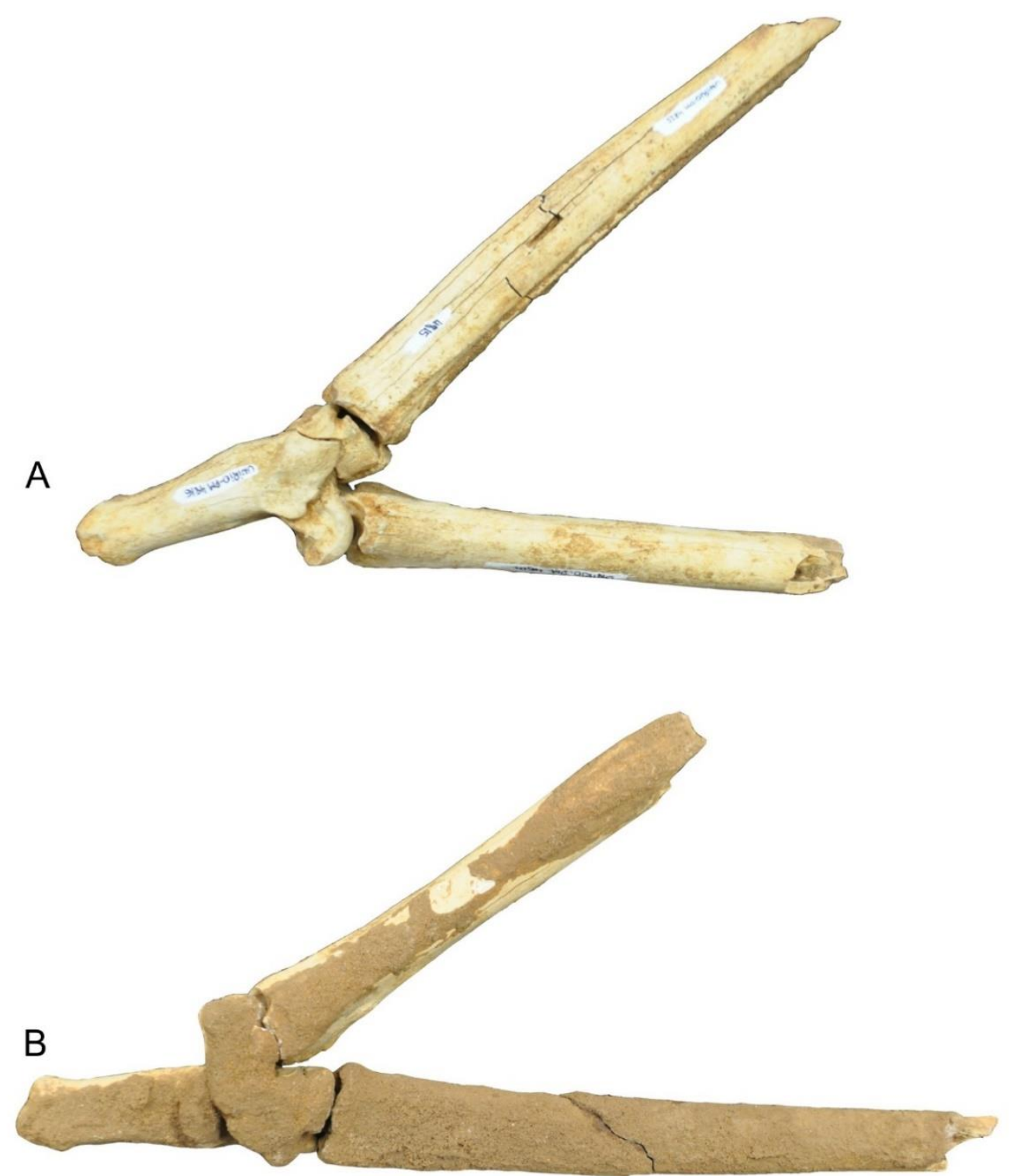

Fig. 4. Articulated elements of a right hindlimb of Mazama americana (UNIRIO-PM 4814, UNIRIO-PM 4815 and UNIRIO-PM 4816). A. medial view of the hindlimb with weathering stage 2 ; B. lateral view of the hindlimb with stage 2 of incrustation. Scale bar $=5 \mathrm{~cm}$. 
A

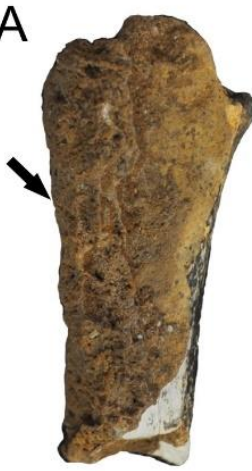

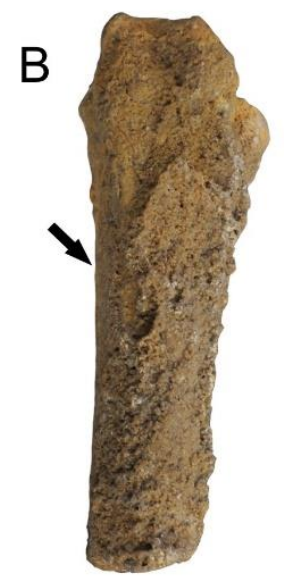
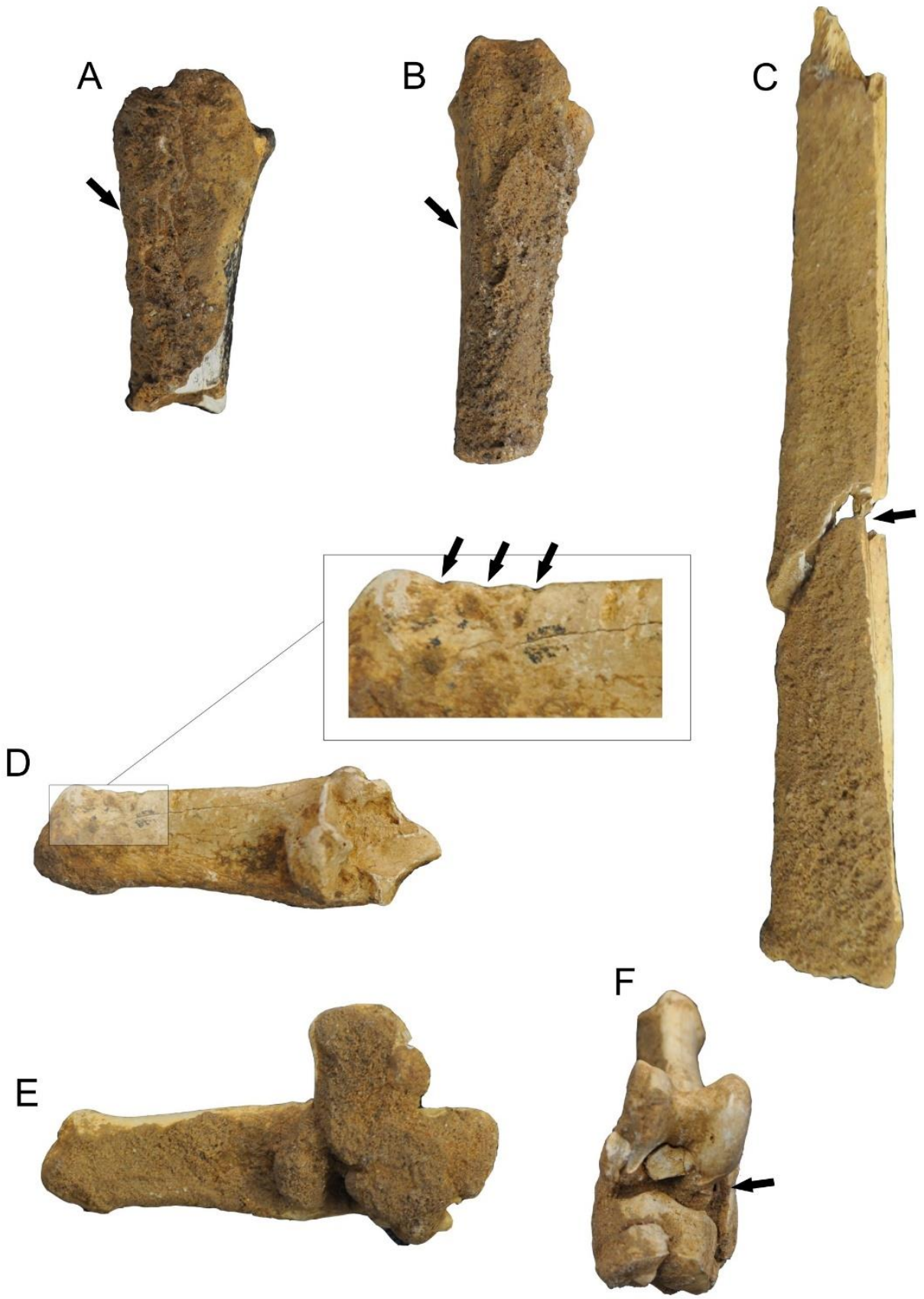

Fig. 5. Taphonomic features observed in the deer remains from Gruta do Urso cave. A. UNIRIO-PM 1310, proximal fragment of left tibia with stage 2 of incrustation; B. UNIRIO-PM 3460, proximal fragment of right tibia with stage 2 of incrustation and permineralization; C. UNIRIO-PM 4815, right metatarsus of fracture produced during the collecting; D. UNIRIO-PM 4813, left calcaneus with tooth marks (scratches); E. UNIRIO-PM 4816, articulated podial elements (calcaneus, astragalus and tarsus); F. UNIRIOPM 4816, view of the articular surfaces of the articulated elements; arrows indicate taphonomic signatures. Scale bar= $5 \mathrm{~cm}$. 
Stage 0 indicates no sign of cracking and possible range to 1 year of exposure; Stage 1, the bone shows cracking parallel to the fiber structure and possible range from 1 to 3 years of subaerial exposure; Stage 2, outermost concentric thin layers of bone shows flacking tending to separate and flake first and possible range from 3 to 5 years of subaerial exposure; finally, the Stages 3, 4 and 5 demonstrate cracking bones more opened or falling apart in situ what indicate a time of exposure more than 5 years until around 30 years (Behrensmeyer, 1978).

Considering that only the Stages 0, 1 and 2 are observed in the deer remains of Gruta do Urso, we interpret a time span of subaerial exposure of five years for the thanatocoenosis analyzed herein. Considering that this process does not occur inside caves, we can infer that the individuals died outside the cave and, then, were transported to inside of it (a peripheral assemblage sensu Araújo-Júnior, 2016). Consequently, we can rule out the idea that the cervid assemblage of Gruta do Urso is a leftover concentration produced by predators or scavengers inside the caves.

Although we can rule out the hypothesis that cervid remains were deposited inside the cave by predators/scavengers, it is not possible to discard completely the action of these organisms during the taphonomic history of the fossil assemblage, as bone removals and scratches have been observed in some specimens. Thus, although neither predation nor scavenging had occurred inside the cave, they occurred sometime outside the Gruta do Urso.

These features are similar to those produced by felids (bone remotions in the epiphyses) and canids (scratches in the diaphyses) (Haynes, 1980; Araújo-Júnior et al., 2011; Dominato et al., 2011).

Considering the shape and size of the traces and the carnivore species recorded in the cave deposit (Rodrigues et al., 2014), it is likely that the bone remotions and scratches have been produced by the large-sized felid Panthera onca (Linnaeus, 1758) and the small-sized canid Cerdocyon thous (Smith, 1839). Furthermore, this hypothesis is based on the distribution of those species in the Cerrado (Savanna) and Caatinga (Deserts and Shrublands) biomes of northeast Brazil and coexists with other species during the Late Pleistocene-Holocene, putting them in the same scenario at the same period.

Likewise the desiccation marks, the overrepresentation of disarticulated elements suggests a time span of subaerial exposure of the carcasses prior to burial (Shipman, 1981; Weigelt, 1989; Behrensmeyer, 1991).

During that time, scavenging, weathering and even the transport may have influenced in the disarticulation of the cervid carcasses outside the cave. However, it is noteworthy the presence of an articulated hindlimb in the fossil assemblage (the right tibia, UNIRIO-PM 4814; the right metatarsus, UNIRIO-PM 4815; and tarsal bones, calcaneus and astragalus, UNIRIO-PM 4816). Additionally, the pattern of curving of the hindlimb is intriguing (Fig. 5).

This pattern matches with that observed in mummified carcasses in an arid climate (Weigelt, 1989; Araújo-Júnior and Marinho, 2013). Thus, considering this evidence, it is likely that an arid climate may have occurred during the biostratinomic phase of the cervid assemblage of Gruta do Urso.

This hypothesis reinforces the idea of the predominance of dry climate which correspond with the Cerrado biome, confirming in a first time the exposition of this material in a elevate temperature and after occurring some event making the transport to the cave.

Regarding the breakage pattern, all fractures observed in the specimens can be assigned to biostratinomic processes (Shipman et al., 1981). Scavenging, trampling and transport have been erected as processes responsible for breaking bones during the biostratinomic phase (Shipman, 1981; Shipman et al., 1981; Behrensmeyer, 1991; Lyman, 1994).

However, considering the bone modifications observed in the cervid remains, trampling (e.g. trample marks) has not been observed (Behrensmeyer et al., 1986) what make this process unlikely as further evidence. We also rule out the hypothesis of the fractures have been produced during the hydraulic transport, but the few evidences with this type of mark (e.g. abrasion) demonstrate a low-energy transport which would not have energy enough to fracture large-sized bones.

The preservation of cervid remains in fine sands, the predominance of the elements of the groups I and II of Voorhies (1969) (phalanges, tibiae and humeri) and the occurrence of minor abrasion are evidence in favor of the hypothesis that the cervid remains experienced a low-energy transport into the cave (Voorhies, 1969; Behrensmeyer, 1975; Shipman, 1981; Lyman, 1994; Eberth et al., 2007a).

However, differences in the staining of some bones indicate that cervid remains experienced fossil diagenetic alterations during different time spans or even different places (Araújo-Júnior et al., 2013). Thus, it is likely that multiple events of specimen inputs - during multiple events of sedimentary deposition into the cave - occurred during the genesis of the cervid assemblage in Gruta do Urso.

A large amount of cervid specimens presents the stage 1 of incrustation. Such feature occurs only on half of the specimens, suggesting that the incrusted portion experienced 
exposure on the water table in the upper part of the Gruta do Urso deposit.

\section{Conclusion}

The cervid fossil accumulation of the Gruta do Urso cave is a peripheral assemblage of individuals of different species that died outside the cave. After the death, the carcasses underwent disarticulation and weathering during a time span between one and five years. During the decay, they experienced scavenging by large-sized felids and small-sized canids. Then, the disarticulated remains and a mummified hindlimb were transported into the cave by multiple events of low-energy hydraulic flows. Inside the cave, some specimens experienced exposure on the water table and incrustation. The taphonomic history of the cervid assemblage seems to have occurred under an arid climate.

\section{Acknowledgments}

We would like to thank the following curators: João Alves and Sergio Maia Vaz (Museu Nacional-UFRJ) and Castor Cartelle (Museu PUC-Minas) for granting us access to the zoological and paleontological collections. Also, we appreciate all technical and logistic support provided during expeditions by Municipality of Aurora de Tocantins, Mr. Wagner Moura and the Sociedade Brasileira de Espeleologia. The authors also thank Conselho Nacional de Desenvolvimento Científico e Tecnológico (CNPq) (401812/2010-3, Edital MCT/CNPq N $\mathrm{N}^{\circ} \quad 32 / 2010$ Fortalecimento da Paleontologia Nacional / Edital 32/2010 Faixa B and 552975/2011, Apoio a Projetos de Pesquisa /Chamada MCTI/CNPq No 23/2011 - Apoio Técnico para Fortalecimento da Paleontologia Nacional), Fundação Carlos Chagas Filho de Amparo à Pesquisa do Estado do Rio de Janeiro (FAPERJ), Coordenação de Aperfeiçoamento de Pessoal de Nível Superior (CAPES) for financial support; the authors thank to D. Mothe for preparing the Figure 1 and P.E.A. Soares for helping in the preparation of the figures 3,4 and 5 .

\section{References}

Andrews, P., 1990. Owls, Caves and Fossils: predation, preservation and accumulation of small mammal bones in caves, with an analysis of the Pleistocene cave faunas from Westbury-sub-Mendip, Somerset, UK, Natural History Museum Publications, London.

Araújo-Júnior, H.I., 2016. Classifying vertebrate assemblages preserved in Quaternary tank deposits: Implications for vertebrate taphonomy and paleoecology. Palaeogeography,
Palaeoclimatology, Palaeoecology 445, 147-152. doi.10.1016/j.palaeo.2015.12.025

Araújo-Júnior, H.I., Marinho, T.S., 2013. Taphonomy of a Baurusuchus (Crocodyliformes, Baurusuchidae) from the Adamantina Formation (Upper Cretaceous, Bauru Basin), Brazil: Implications for preservational modes, time resolution and paleoecology. Journal of South American Earth Sciences 47, 90-99. doi.10.1016/j.jsames.2013.07.006

Araújo-Júnior, H.I., Porpino, K.O., Ximenes, C.L., Bergqvist, L.P., 2013. Unveiling the taphonomy of elusive natural tank deposits: a study case in the Pleistocene of northeastern Brazil. Palaeogeography, Palaeoclimatology, Palaeoecology 378, 5274. doi.10.1016/j.palaeo.2013.04.001

Araújo-Júnior, H.I., Porpino, K.O., Bergqvist, L.P., 2011. Marcas de dentes de carnívoros/carniceiros em mamíferos pleistocênicos do Nordeste do Brasil. Revista Brasileira de Paleontologia 14, 291-296. doi.10.4072/rbp.2011.3.08

Auler, A.S., Farrant, A.R. 1999. A brief introduction to karst and caves in Brazil. Proceedings University of Bristol Spelaeological Society 20, 187-200.

Auler, A.S., Piló, L.B., Smart, P.L., Wang, X., Hoffmann, D., Richards, D.A., Edwards, R.L., Neves, W.A., Cheng, H., 2006. U-series dating and Taphonomy of Quaternary vertebrates from Brazilian caves. Palaeogeography, Palaeoclimatology, Palaeoecology 240, 508-522. doi.10.1016/j.palaeo.2006.03.002

Auler, A.S., Smart, P.L., Wang, X., Piló L.B., Edwards, R.L., Cheng, H. 2009. Cyclic sedimentation in Brazilian caves: mechanisms and palaeoenvironmental significance. Geomorphology 106, 142-153.

Avilla, L.S., Müller, L., Gasparini, G., Soibelzon, L., Absolon, B., Pego, F.B., Costa, R., Kinoshita, A., Figueiredo, A.M.G., Baffa, O., 2013. The northernmost record of Catagonus stenocephalus (Lund in Reinhardt, 1880) (Mammalia, Cetartiodactyla) and its palaeoenvironmental and palaeobiogeographical significance. Journal of South American Earth Sciences 42, 39-46.

Badgley, C., 1986. Counting individuals in mammalian fossil assemblages from fluvial environments. Palaios 1, 328-338.

Behrensmeyer, A.K., 1991. Terrestrial vertebrate accumulations. In: Allison, P.A., Briggs, D.E.G. (eds.), Taphonomy: Releasing the Data Locked in the Fossil Record, Plenum Press, New York, pp. 291-335.

Behrensmeyer, A.K., Gordon, K.D., Yanagi, G.T., 1986. Trampling as a cause of bone surface damage and pseudocutmarks. Nature 319, 768-771.

Behrensmeyer, A.K., 1978. Taphonomic and ecologic information from bone weathering. Paleobiology 4, 150-162.

Behrensmeyer, A.K., 1975. The taphonomy and paleoecology of Plio-Pleistocene vertebrate assemblage east of Lake Rudolf, Kenya. Bulletin of the Museum of Comparative Zoology 146, 473-578.

Brain, C.K. 1995. The influence of climatic changes on the completeness of the early hominid record in Southern African 
caves, with particular reference to Swartkrans. In: Vrba, E.S., Denton, G.H., Partridge, T.C., Burckle, L.H. (eds.), Paleoclimate and Evolution with Emphasis on Human Origins, Yale University Press, New Haven, pp. 451-458.

Brook, G.A., Cowart, J.B., Brandt, S.A., Scott, L., 1997. Quaternary climatic change in southern and eastern Africa during the last $300 \mathrm{ka}$ : the evidence from caves in Somalia and the Transvaal region of South Africa. Zeitschrift für Geomorphologie, Supplement band 108, 15-48.

Cabral-de-Carvalho, J.N., Campos-e-Silva, A., Oliveira, L.D.D., Fernandes, M., Carvalho, S.G., 1969. A Paleontologia no Rio Grande do Norte. Arquivos do Instituto de Antropologia 1, 1 40.

Cartelle, C., 1992. Edentata e megamamíferos herbívoros extintos da Toca dos Ossos (Ourolândia, BA, Brasil). Ph. D. Dissertation, Universidade Federal de Minas Gerais, 516 p.

Castro, M.C., Avilla, L.S., Freitas, M.L., Carlini, A.A., 2013. The armadillo Propraopus sulcatus (Mammalia: Xenarthra) from the late Quaternary of northern Brazil and a revised synonymy with Propraopus grandis. Quaternary International 317, 80-87. doi.10.1016/j.quaint.2013.04.032.

Cione, A.L., Tonni, E.P., 1999. Biostratigraphy and chronological scale of uppermost Cenozoic in the Pampean area, Argentina. In: Tonni, E.P., Cione, A.L. (eds.), Quaternary vertebrate palaeontology in South America. Quaternary of South America and Antarctic Peninsula 12, 23-52.

Cione, A.L., Tonni, E.P., 2005. Bioestratigrafía basada en mamíferos del Cenozoico Superior de la Provincia de Buenos Aires, Argentina. In: Barrio, R.E., Etcheverry, R.O., Caballé, M.F., Llambias, E. (eds.), Geología y Recursos Minerales de la Provincia de Buenos Aires. La Plata, Quick Press, pp. 183-200.

Companhia de Pesquisa de Recursos Minerais: CPRM. Rochas Carbonáticas do Grupo Bambuí na região Nordeste do Estado de Goiás. URL: http:/ /www.cprm.gov.br/publique/RecursosMinerais/Recursos-Minerais-do-Brasil/Rochas-Carbonaticasdo-Grupo-Bambui-na-Regiao-Nordeste-do-Estado-de-Goias261.html. Access 01.04.2016

Dardenne, M.A., 1978. Síntese sobre a estratigrafia do Grupo Bambuí no Brasil Central. In: $30^{\circ}$ Congresso Brasileiro de Geologia. Sociedade Brasileira de Geologia, Recife, pp. 597610.

Dardenne, M.A., Walde, H.H.G., 1979. A estratigrafia dos Grupos Bambuí e Macaúbas no Brasil Central. In: $1^{\circ}$ Simpósio de Geologia de Minas, Sociedade Brasileira de Geologia, Belo Horizonte, pp. 43-54.

Dominato, V.H.S., Mothé, D., Costa-da-Silva, R., Avilla, L.S., 2011. Evidence of scavenging on remains of the gomphothere Haplomastodon waringi (Proboscidea: Mammalia) from the Pleistocene of Brazil: Taphonomic and paleoecological remarks. Journal of South American Earth Sciences 31, 171 177. Doi.10.1016/j.jsames.2011.01.002

Eberth, D.A., Rogers, R.R., Fiorillo, A.R., 2007a. A Practical Approach to the Study of Bonebeds. In: Rogers, R.R., Eberth,
D.A., Fiorillo, A.R. (eds.), Bonebeds: genesis, analysis and paleobiological significance. The University of Chicago Press, Chicago, pp. 265-332.

Eberth, D.A., Shannon, M., Noland, B.G., 2007b. A Bonebeds Database: Classification, Biases and Patterns of Occurrence. In: Rogers, R.R., Eberth, D.A., Fiorillo, A.R. (eds.), Bonebeds: genesis, analysis and paleobiological significance. The University of Chicago Press, Chicago, pp. 103-220.

Gasparini, G.M., Holanda, E.C., Araújo-Júnior, H.I., Avilla, L.S., 2015. A Quaternary very young juvenile Tapirus Brisson, 1762 (Mammalia, Perissodactyla) from a cave deposit in northern Brazil: taxonomy and taphonomy. Historical Biology 28, 803811. doi.10.1080/08912963.2015.1035269.

Haynes, G., 1980. Evidence of carnivore gnawing of Pleistocene and recent mammalian bones. Paleobiology 6, 341-351.

Haynes, G., 1983. A guide for differentiating mammalian carnivore taxa responsible for gnaw damage to herbivore limb bones. Paleobiology 9, 164-172.

Hill, A.P., 1980. Early post-mortem damage to the remains of some contemporary east African mammals. In: Behrensmeyer, A.K., Hill, A.P. (eds.), Fossils in the Making: Vertebrate Taphonomy and Paleoecology. University of Chicago Press, Chicago, pp. 131-152.

Hubbe, A., Auler, A., 2012. A large Cervidae Holocene accumulation in Eastern Brazil: an example of extreme taphonomical control in a cave environment. International Journal of Speleology 41, 297-305. doi.10.5038/1827806X.41.2.15

Hubbe, A., Haddad-Martim, P.M., Hubbe, M., Mayer, E.L., Strauss, A., Auler, A., Piló, L.B., Neves, W.A., 2011. Identification and importance of critical depositional gaps in pitfall cave environments: The fossiliferous deposit of Cuvieri Cave, eastern Brazil. Palaeogeography, Palaeoclimatology, Palaeoecology 312, 66-78. doi: 10.1016/j.palaeo.2011.09.010

Lyman, R.L., 1994. Vertebrate Taphonomy. Cambridge University Press, Cambridge.

Mikuláš, R., Kadlecová, E., Fejfar, O., Dvořák, Z., 2006. Three new ichnogenera of biting and gnawing traces on reptilian and mammalian bones: A case study from the Miocene of the Czech Republic. Ichnos 13, 1-15. doi.10.1080/10420940600850729

Oliveira, E.V., Villa Nova, P., Goin, F.J., Avilla, L.S., 2011. New marsupial (Mammalia, Didelphimorphia) from the Quaternary of northern Brazil: a distinct lineage within Dedelphoidea? Zootaxa 3041, 51-62.

Palmer, A.N., 1991. Origin and morphology of limestone caves. Geological Society of America Bulletin 103, 1-21.

Pereira, C., 2015. Os Cervidae (Cetartiodactyla: Mammalia) fósseis do Quaternário do Norte do Brasil: Taxonomia, Anatomia e Tafonomia baseada na análise do esqueleto pós-craniano. Monografia de graduação, Curso de Graduação em Ciências Biológicas, Universidade Federal do Estado do Rio de Janeiro, 40 p. 
Pirrone, C.A., Buatois, L.A., Bromley, R.G., 2014. Ichnotaxobases for bioerosion trace fossils in bones. Journal of Paleontology 88, 195-203. doi.10.1666/11-058

Rodrigues S., Avilla L.S., Soibelzon L.H., Bernardes C., 2014. Late Pleistocene carnivores (Carnivora: Mammalia) from a cave sedimentary deposit in northern Brazil. Anais da Academia Brasileira de Ciências 86(4), 1641-1655.

Rodriguez, S.G., Soibelzon, L.H., Rodrigues, S., Morgan, C.C., Bernardes, C., Avilla, L., Lynch, E. 2013. First Record of Procyon cacrivorus (Curvier, 1798) (Carnivora, Procyonidae) in stratigraphic context in the Late Pleistocene of Brazil. Journal of South America Earth Sciences 45, 1-5.

Scherer, C. 2009. Os camelidae lamini (Mammalia, Artiodactyla) do Pleistoceno da América do Sul: aspectos taxonômicos e filogenéticos. Tese de doutorado, Programa de Pós-graduação em Geociências, Universidade Federal do Rio Grande do Sul, $460 \mathrm{p}$.

Schmid, E. 1972. Atlas of animal bones. Elsevier Publishing Company. Amsterdam, London, New York.

Shipman, P., 1981. Life History of a Fossil: An Introduction to Taphonomy and Paleoecology. Harvard University Press, Cambridge.

Shipman, P., Bosler, W., Davis, K.L., 1981. Butchering of giant geladas at an Acheulian site. Current Anthropology 46, 77-86.
Simms, M.J., 1994. Emplacement and preservation of vertebrates in caves and fissures. Zoological Journal of the Linnean Society 112, 261-283.

Sisson, S., Grossman, J.D., 2008. Anatomia dos animais domésticos. Editora Guanabara Koogan S.A., Rio de Janeiro.

Soibelzon, E., Avilla, L.S., Castro, M., 2015. The cingulates (Mammalia: Xenarthra) from the late Quaternary of northern Brazil: Fossil records, paleoclimates and displacements in America. Quaternary International 30, 1-8.

Villa Nova, P., Avilla, L.S., Oliveira, E.V., 2015. Didelphidae marsupials (Mammalia, Didelphimorphia) from the Late Pleistocene deposit of the Gruta dos Moura Cave, northern Brazil. Anais da Academia Brasileira de Ciências 87, 193-208.

Voorhies, M.R., 1969. Taphonomy and populations dynamics of an early Pliocene vertebrate fauna, Knox County, Nebraska. Contributions to Geology 1, 1-69.

Weigelt, J., 1989. Recent vertebrate carcasses and their paleobiological implications. University of Chicago Press, Chicago.

Zampaulo, R.A., Ferreira, R.L., 2009. Terrestrial cave invertebrate diversity in nine caves in the municipality of Aurora do Tocantins (TO). In: Anais do $30^{\circ}$ Congresso Brasileiro de Espeleologia, Proceedings, Minas Gerais, pp. 267-274. 
Appendix 1. List of the deer specimens evaluated in this study and their degree of taphonomic signatures. IP= "Irregular and perpendicular to the longest bone axis" fracture.

\begin{tabular}{|c|c|c|c|c|c|c|c|}
\hline Specimen & Species & $\begin{array}{l}\text { Skeletal } \\
\text { element }\end{array}$ & $\begin{array}{c}\text { Location in the } \\
\text { cave }\end{array}$ & $\begin{array}{c}\text { Weathering } \\
\text { stages }\end{array}$ & $\begin{array}{c}\text { Incrustation } \\
\text { stages }\end{array}$ & $\begin{array}{l}\text { Type of } \\
\text { fracture }\end{array}$ & $\begin{array}{l}\text { Degree of } \\
\text { abrasion }\end{array}$ \\
\hline UNIRIO-PM 1310 & Mazama americana & Left tibia & Conduit entrance & Stage 1 & Stage 2 & IP & Unobservable \\
\hline UNIRIO-PM 3454 & Mazama gouazoubira & Right humerus & Main hall & \multirow{2}{*}{$\begin{array}{c}\text { Stage } 1 \\
\text { Unobservable }\end{array}$} & Stage 1 & IP & No abrasion \\
\hline UNIRIO-PM 3455 & Mazama gouazoubira & Right metatarsus & Curve 5 & & Stage 1 & IP & $\begin{array}{l}\text { Moderate } \\
\text { abrasion }\end{array}$ \\
\hline UNIRIO-PM 3456 & Mazama gonazoubira & Right calcaneus & Unknown & Stage 1 & Stage 1 & IP & No abrasion \\
\hline UNIRIO-PM 3457 & Mazama gonazoubira & Right metacarpus & Unknown & Stage 1 & Stage 1 & IP & No abrasion \\
\hline UNIRIO-PM 3458 & Mazama gonazoubira & Left metacarpus & Unknown & Stage 1 & Stage 1 & IP & No abrasion \\
\hline UNIRIO-PM 3459 & Mazama gonazoubira & Left femur & Unknown & Stage 0 & Stage 1 & IP & No abrasion \\
\hline UNIRIO-PM 3460 & Mazama americana & Right tibia & Curve 4 & Stage 1 & Stage 2 & IP & No abrasion \\
\hline UNIRIO-PM 3461 & Blastocerus dichotomus & Right humerus & Curve 1 & Stage 1 & Stage 0 & IP & No abrasion \\
\hline UNIRIO-PM 3462 & Mazama gouazoubira & Right phalanx & Unknown & Stage 1 & Stage 1 & No fracture & No abrasion \\
\hline UNIRIO-PM 3463 & Mazama gouazoubira & Right metatarsus & Unknown & Stage 1 & Stage 1 & IP & No abrasion \\
\hline UNIRIO-PM 3464 & Mazama gonazoubira & Left tibia & Unknown & Stage 1 & Stage 1 & IP & No abrasion \\
\hline UNIRIO-PM 3465 & Mazama gonazoubira & Navicular & Unknown & Stage 0 & Stage 1 & No fracture & No abrasion \\
\hline UNIRIO-PM 3467 & Mazama gonazoubira & Right astragalus & Unknown & Stage 1 & Stage 1 & No fracture & No abrasion \\
\hline UNIRIO-PM 3468 & Mazama gouazoubira & Left astragalus & Unknown & Unobservable & Stage 0 & No fracture & No abrasion \\
\hline UNIRIO-PM 3469 & Mazama gouazoubira & Left calcaneus & Unknown & Stage 1 & Stage 1 & IP & No abrasion \\
\hline UNIRIO-PM 3470 & Mazama gonazoubira & Left astragalus & Unknown & Stage 1 & Stage 1 & No fracture & No abrasion \\
\hline UNIRIO-PM 3471 & Mazama gonazoubira & Right humerus & Unknown & Stage 1 & Stage 1 & IP & No abrasion \\
\hline UNIRIO-PM 3472 & Mazama gouazoubira & Left humerus & Unknown & Stage 1 & Stage 1 & IP & No abrasion \\
\hline UNIRIO-PM 3473 & Mazama gonazoubira & Left metacarpus & Unknown & Stage 1 & Stage 1 & IP & No abrasion \\
\hline UNIRIO-PM 3474 & Mazama gonazoubira & Right phalanx & Unknown & Stage 0 & Stage 1 & No fracture & No abrasion \\
\hline UNIRIO-PM 3476 & Mazama gonazoubira & Right radius & Curve 5 & Stage 1 & Stage 1 & Spiral fracture & No abrasion \\
\hline UNIRIO-PM 3477 & Mazama americana & Right metatarsus & Curve 4 & Stage 1 & Stage 1 & IP & No abrasion \\
\hline UNIRIO-PM 4813 & Mazama americana & Left calcaneus & Curve 5 & Stage 1 & Stage 1 & No fracture & No abrasion \\
\hline UNIRIO-PM 4814 & Mazama americana & Right tibia & Curve 3 & Stage 1 & Stage 1 & IP & No abrasion \\
\hline UNIRIO-PM 4815 & Mazama americana & Right metatarsus & Curve 3 & Stage 2 & Stage 2 & IP & No abrasion \\
\hline UNIRIO-PM 4816 & Mazama americana & $\begin{array}{l}\text { Associated right } \\
\text { podials }\end{array}$ & Curve 3 & Stage 1 & Stage 2 & No fracture & No abrasion \\
\hline UNIRIO-PM 5665 & Mazama americana & Right metatarsus & Curve 2 & Stage 1 & Stage 1 & IP & No abrasion \\
\hline
\end{tabular}


Appendix 2. Color of skeletal elements, staining and incrustation according to the Munsell Color Chart.

\begin{tabular}{|c|c|c|c|}
\hline Specimen & Skeletal element & Staining & Incrustation \\
\hline UNIRIO-PM 1310 & Yellow 8/6 (YELLOW Hue 5Y) & Black olive (YELLOW Hue 5Y) & Yellowish brown (YELLOW-RED Hue 10YR) \\
\hline UNIRIO-PM 3454 & Yellow 8/6 (YELLOW Hue 5Y) & $\begin{array}{c}\text { Grayish olive } 5 / 3 \text { (YELLOW Hue } 5 Y \text { ) } \\
\text { and brown } 5 / 8 \text { (YELLOW-RED Hue } \\
7,5 Y R \text { ) }\end{array}$ & Yellow 8/8 (YELLOW Hue 5Y) \\
\hline UNIRIO-PM 3455 & Yellow 8/4 (YELLOW Hue 5Y) & - & Yellowish 7/6 (YELLOW-RED Hue 2,5YR) \\
\hline UNIRIO-PM 3456 & Yellow 8/6 (YELLOW Hue 5Y) & - & Brown 5/8 (YELLOW-RED Hue 10YR) \\
\hline UNIRIO-PM 3457 & Yellow 8/4 (YELLOW Hue 5Y) & Grayish olive 5/3 (YELLOW Hue 5Y) & Yellowish 7/6 (YELLOW-RED Hue 2,5YR) \\
\hline UNIRIO-PM 3458 & Yellow 8/6 (YELLOW Hue 5Y) & - & Brown 6/8 (YELLOW-RED Hue 2,5YR) \\
\hline UNIRIO-PM 3459 & Yellow 8/6 (YELLOW Hue 5Y) & - & Brown $6 / 8$ (YELLOW-RED Hue 10YR) \\
\hline UNIRIO-PM 3460 & Yellow 8/6 (YELLOW Hue 5Y) & Black olive (YELLOW Hue 5Y) & Bright 6/6 (YELLOW-RED Hue 2,5YR) \\
\hline UNIRIO-PM 3461 & Yellow 8/6 (YELLOW Hue 5Y) & - & - \\
\hline UNIRIO-PM 3462 & Yellow 8/6 (YELLOW Hue 5Y) & - & Yellowish 5/6 (YELLOW-RED Hue 10YR) \\
\hline UNIRIO-PM 3463 & Yellow 8/6 (YELLOW Hue 5Y) & Grayish olive 5/3 (YELLOW Hue 5Y) & Gray 5/6 (YELLOW-RED Hue 2,5YR) \\
\hline UNIRIO-PM 3464 & Yellow 8/6 (YELLOW Hue 5Y) & - & Brown 6/8 (YELLOW-RED Hue 2,5YR) \\
\hline UNIRIO-PM 3465 & Yellow 8/6 (YELLOW Hue 5Y) & $\begin{array}{c}\text { Brown } 4 / 4 \text { (YELLOW-RED Hue } \\
\text { 2,5YR) }\end{array}$ & Yellow orange $7 / 8$ (YELLOW-RED Hue 10YR) \\
\hline UNIRIO-PM 3467 & Yellow 8/6 (YELLOW Hue 5Y) & - & Yellowish 5/6 (YELLOW-RED Hue 10YR) \\
\hline UNIRIO-PM 3468 & Yellow 8/6 (YELLOW Hue 5Y) & - & - \\
\hline UNIRIO-PM 3469 & Yellow 8/6 (YELLOW Hue 5Y) & - & Brown 5/8 (YELLOW-RED Hue 10YR) \\
\hline UNIRIO-PM 3470 & Yellow 8/4 (YELLOW Hue 5Y) & - & Brown 6/8 (YELLOW-RED Hue 10 YR) \\
\hline UNIRIO-PM 3471 & Yellow 8/6 (YELLOW Hue 5Y) & - & Brown 6/8 (YELLOW-RED Hue 10YR) \\
\hline UNIRIO-PM 3472 & Yellow 8/6 (YELLOW Hue 5Y) & - & Brown 6/8 (YELLOW-RED Hue 10YR) \\
\hline UNIRIO-PM 3473 & Yellow 8/4 (YELLOW Hue 5Y) & - & Bright 6/6 (YELLOW-RED Hue 2,5YR) \\
\hline UNIRIO-PM 3474 & Yellow 8/6 (YELLOW Hue 5Y) & - & Yellowish 5/6 (YELLOW-RED Hue 10YR) \\
\hline UNIRIO-PM 3476 & Yellow 8/6 (YELLOW Hue 5Y) & - & Yellow 7/8 (YELLOW-RED Hue 2,5YR) \\
\hline UNIRIO-PM 3477 & Yellow 8/6 (YELLOW Hue 5Y) & Grayish olive 5/3 (YELLOW Hue 5Y) & Yellowish 7/6 (YELLOW-RED Hue 2,5YR) \\
\hline UNIRIO-PM 4813 & Yellow 8/6 (YELLOW Hue 5Y) & - & Bright 6/6 (YELLOW-RED Hue 2,5YR) \\
\hline UNIRIO-PM 4814 & Yellow 8/6 (YELLOW Hue 5Y) & - & Brown 6/8 (YELLOW-RED Hue 2,5YR) \\
\hline UNIRIO-PM 4815 & Yellow 8/6 (YELLOW Hue 5Y) & - & Brown 6/8 (YELLOW-RED Hue 2,5YR) \\
\hline UNIRIO-PM 4816 & Yellow 8/6 (YELLOW Hue 5Y) & - & Brown 6/8 (YELLOW-RED Hue 2,5YR) \\
\hline UNIRIO-PM 5665 & Yellow 8/6 (YELLOW Hue 5Y) & - & Brown 6/8 (YELLOW-RED Hue 10YR) \\
\hline
\end{tabular}

